\title{
ANALISA KELAYAKAN RANCANGAN LANSEKAP RUANG TERBUKA HIJAU (RTH) SUNGAI MATI CISANGKUY BERDASARKAN ASPEK FINANSIAL
}

\author{
Citra Utami \\ Dosen Pengajar Program Studi Teknik Sipil, Fakultas Teknik, UMSU, Medan \\ Surel : citra.utami88@gmail.com \\ Diterima : 30 Oktober 2017; Disetujui : 06 November 2017
}

\begin{abstract}
ABSTRAK
Rancangan Lansekap Ruang Terbuka Hijau (RTH) Sungai Mati Cisangkuy merupakan salah satu gagasan penanganan banjir, penataan kembali, dan pemanfaatan sungai mati. Rancangan tersebut berupa dinding penahan banjir, pompa air, pengolahan limbah domestik, dan pemanfaatan tata guna lahan. Analisa dilakukan berdasarkan aspek finansial menggunakan indikator nilai NPV, BCR dan IRR. Analisa kelayakan rancangan tersebut dilakukan untuk menilai apakah rancangan layak direalisasikan. Berdasarkan analisa di atas, dapat disimpulkan bahwa Rancangan Lansekap RTH Sungai Mati Cisangkuy tidak layak
\end{abstract}

Kata Kunci : Analisa Kelayakan, aspek finansial, Lansekap RTH

\begin{abstract}
RTH Landscape design at Cisangkuy Oxbow Lake is one of the ideas of flood mitigation, rearrangement, and oxbow lake utilization. The design consists of flood retaining walls, water pumps, domestic waste management, and land use utilization. The analysis is based on the financial aspect using NPV, BCR and IRR value. The feasibility analysis is undertaken to assess whether the design is feasible to be realized. Based on the analysis, it is concluded that the design is not feasible.
\end{abstract}

Keywords: Feasibility Analysis, Financial Aspect, RTH Landscape

\section{Pendahuluan}

Program normalisasi dan sudetan yang dilakukan oleh Direktorat Jenderal Sumber Daya Air terhadap Sungai Citarum dan anak sungainya merupakan salah satu upaya penanggulangan banjir yang terjadi di sepanjang Sungai Citarum dan daerah sekitarnya. Program sudetan tersebut menciptakan sungai mati (oxbow lake) yang terbengkalai dan permasalahan utama berupa banjir belum dapat di atasi. Salah satu Sungai Mati hasil program tersebut adalah Sungai Mati Cisangkuy yang terletak di Kelurahan Andir Kecamatan Baleendah Kabupaten Bandung. Melihat permasalahan banjir yang masih belum dapat ditanggulangi muncul suatu gagasan penanggulangan banjir berupa Rancangan Lansekap Sungai Mati Cisangkuy sebagai Ruang terbuka Hijau Publik yang dikemukakan oleh Reny Rachmawati (2013). Selain berisi gagasan penanggulangan banjir, rancangan tersebut juga berupa gagasan penataan ruang kembali terhadap Sungai Mati Cisangkuy dan sempadannya. Rancangan yang dinilai baik dari sisi lansekap belum tentu baik bila dinilai dari aspek lain. Oleh karena itu, diperlukan penilaian kelayakan terhadap aspek lain untuk menentukan apakah suatu rancangan layak atau tidak untuk direalisasikan. Salah satu aspek tersebut adalah aspek finansial. Aspek tersebut mempengaruhi keputusan yang akan diambil menyangkut investasi yang akan dilakukan.

2. Kajian Pustaka

2.1 Analisa Kelayakan

Dalam upaya mengantisipasi risiko ketidakpastian dari investasi yang dilakukan 
maka diperlukan penilaian terhadap aspek aspek kelayakan investasi. Aspek yang ditinjau dalam melakukan analisa kelayakan adalah sebagai berikut (Kadariah, 1988) : aspek teknis, aspek managerial dan administratif, aspek organisasi, aspek komersial, aspek finansial, aspek ekonomi, aspek legal, dan aspek lingkungan.

Analisa kelayakan dilakukan berdasarkan tahapan - tahapan mulai dari aspek yang utama. Tahapan atau prosedur analisa kelayakan suatu investasi dapat dilihat pada gambar 1 berikut

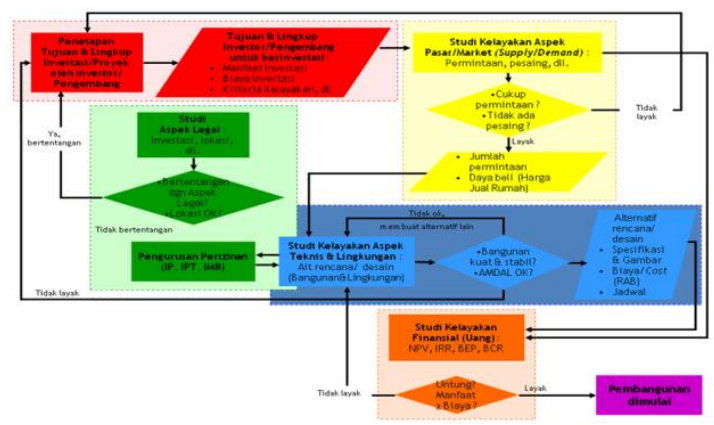

Gambar 1. Prosedur analisa kelayakan atau Hubungan berbagai aspek kelayakan (Sumber : Bahan kuliah studi kelayakan investasi, Purnomo Soekirno (2013))

\subsection{Kelayakan Finansial}

Analisa kelayakan finansial dilakukan dengan menggunakan indikator kelayakan sebagai berikut :

\section{a. Net Present Value (NPV)}

$$
N P V=\sum_{t=0}^{n} \frac{B_{t}-C_{t}}{(1+r)^{t}}
$$

Dimana : $\mathrm{B}=$ Benefit (manfaat), $\mathrm{C}=$ Cost (biaya), $\mathrm{t}=$ waktu dan $\mathrm{r}=$ suku bunga $(\mathrm{i})$

b. Benefit Cost Ratio (BCR)

$$
\begin{aligned}
& \text { BCR }=\frac{\text { Equivalent Annual Total Benefits }}{\text { Equivalent Annual Total Costs }} \\
& \text { BCR }=\frac{\text { Present Worth Total Benefits }}{\text { Present Worth Total Costs }}
\end{aligned}
$$

c. Internal Rate Of Return (IRR)

$$
\begin{aligned}
& \sum_{t=0}^{n} \frac{B_{t}-C_{t}}{(1+r)^{t}}=0 \\
& \left(B_{0}-C_{0}\right)+\frac{B_{1}-C_{1}}{(1+r)^{1}}+\cdots+\frac{B_{n}-C_{n}}{(1+r)^{n}}=0
\end{aligned}
$$

\section{Dimana :}

$\mathrm{B}=$ Benefit (manfaat), $\mathrm{C}=$ Cost (biaya), $\mathrm{n}=$ waktu, $\mathrm{r}=$ IRR

\subsection{Rancangan Lansekap RTH Sungai Mati Cisangkuy}

Rancangan lansekap Sungai Mati Cisangkuy sebagai RTH Publik merupakan suatu upaya penanggulangan banjir dan penataan kembali Sungai Mati Cisangkuy. Rancangan terdiri dari :

1) Sistem dinding penahan banjir. Rancangan dimensi dinding penahan banjir berdasarkan elevasi muka air banjir maksimum. Dinding penahan banjir merupakan suatu sistem tertutup yang mengelilingi kawasan rancangan. Dalam menjaga fungsi aksesibilitas masyarakat maka terdapat pintu bukaan dan ramp.

2) Sistem pompa air. Pompa air dibutuhkan untuk sirkulasi sungai mati dan menjaga elevasi muka air sungai mati rencana.

3) Sistem pengolahan limbah domestik. Pengolahan limbah domestik merupakan suatu upaya untuk memperbaiki kondisi sanitasi di kawasan rancangan. Pengolahan limbah domestik terdiri dari pengolahan limbah primer berupa septictank komunal dan pengolahan limbah sekunder berupa constructed wetland.

4) Pemanfaatan tata guna lahan. Upaya menjaga keberlangsungan sungai mati dan pemberdayaan masyarakat dilakukan dengan pemanfaatan lahan sebagai lahan produksi buah dan sayur, tambak ikan, dan ruang komunal.

Rancangan Lansekap Sungai Mati Cisangkuy dapat dilihat pada gambar berikut.

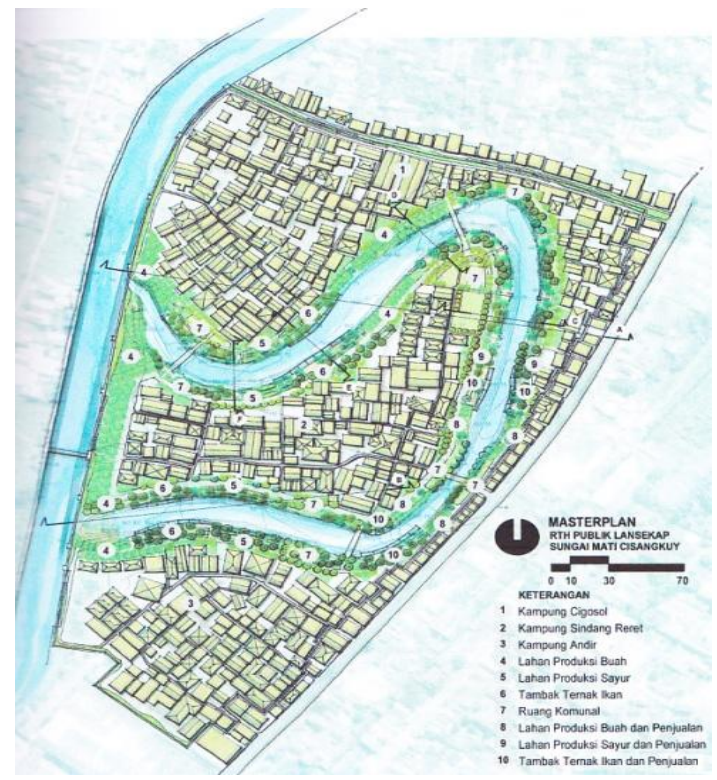

Gambar 2. Rancangan Masteplan Lansekap Ruang Terbuka Hijau (RTH) Sungai Mati Cisangkuy (Sumber : Tesis Reny Rachmawati, 2013) 


\section{Analisa Kelayakan Rancangan Lansekap Ruang Terbuka Hijau (RTH) Sungai Mati Cisangkuy Berdasarkan Aspek Finansial}

\section{Metodologi}

Analisa kelayakan dilakukan dengan menghitung nilai NPV, BCR, dan IRR. Biaya biaya(cost) yang dihitung terdiri dari biaya konstruksi, biaya operasi dan pemeliharaan, dan biaya penyusustan (depresiasi). Dalam menghitung biaya tersebut menggunakan harga pasar. Sedangkan manfaat(benefit) yang diperoleh hanya berupa pengurangan biaya yang diakibatkan oleh banjir yang dirasakan oleh masyarakat yang bersifat tangible meliputi hasil panen lahan produksi buah dan sayur dan tambak ikan, penguranagn biaya kerusakan harta benda dan rumah akibat banjir, dan berkurangnya pendapatan masyarakat yang hilang akibat banjir.

Perhitungan nilai NPV, BCR, dan IRR menggunakan beberapa asumsi yang ditetapkan antara lain :

1) Umur ekonomis rencana bangunan adalah 30 tahun.

2) Suku bunga yang digunakan sebesar $10 \%$ pertahun. Penetapan suku bunga ini lebih besar daripada BI rate Januari 2014 sebesar 7.5\% (sumber : Data BI Rate Bank Sentral $\mathrm{RI})$.

3) Suku bunga pinjaman investasi sebesar $12 \%$ pertahun.

Skema pinjaman terhadap investasi terdiri dari $0 \%$ pinjaman (anggaran pemerintah seluruhnya), $30 \%$ pinjaman $70 \%$ anggaran pemerintah, dan $50 \%$ pinjaman $50 \%$ anggaran pemerintah

\section{Hasil dan Pembahasan}

Hasil perhitungan biaya dan manfaat kemudian dimasukkan ke persamaan (1),(3) dan (5) untuk memperoleh nilai NPV, BCR dan IRR.

Hasil perhitungan indikator kelayakan menggunakan 3 skema pendanaan adalah sebagai berikut :

1) Pendanaan dengan anggaran pemerintah seluruhnya.

NPV sebesar Rp -8.686.747.824,- , BCR sebesar 0,71, dan IRR sebesar 6,49\%.

2) Pendanaan dengan anggaran pemerintah dan pinjaman.

a) Pinjaman $30 \%$ dari Investasi NPV sebesar Rp -18.187.407.104,- , BCR sebesar 0,40, dan IRR sebesar 3,25\%.

b) Pinjaman $50 \%$ dari Investasi NPV sebesar Rp -24.505.301.443,- , BCR sebesar 0,22 dan IRR sebesar 1,42\%.
5 Simpulan

Setelah dilakukannya penelitian, maka diperoleh beberapa simpulan sebagai berikut:

1) Nilai NPV dengan 2 skema pendanaan menunjukkan bahwa investasi tidak sebanding dengan manfaat (benefit) yang diperoleh.

2) Nilai BCR dengan 2 skema pendanaan menunjukkan biaya (cost) lebih besar daripada manfaat (benefit).

3) Nilai IRR dengan 2 skema pendanaan lebih kecil daripada suku bunga bank dan suku bunga pinjaman investasi.

4) Nilai NPV, BCR dan IRR yang diperoleh menunjukkan bahwa rancangan tersebut tidak layak direalisasikan dari aspek finansial.

\section{Daftar Pustaka}

Ariyoto, Kresnohadi. 1995. Feasibility Study. Jakarta : Mutiara Sumber Widya

Harris, Charles W., Nicholas T. Dines. Time Savers Standard For Lanscape Architecture. 1995. McGraw-Hill Co. Singapore.

Kadariah. 1998. Evaluasi Proyek Analisa Ekonomi. Jakarta : Lembaga Penerbit Fakultas Ekonomi Universitas Indonesia.

Maryono, Agus. (2006). Pengelolaan Sungai: Pembangunan Sungai, Dampak, dan Restorasi Sungai. Alami, Vol.11 Nomor 1 Tahun 2006.

Mutiawati, Siska Hilmi. (2013). Tesis : Studi Pengembangan Sungai Mati di Sub DAS Citarum Hulu untuk Waterpark. ITB.

Peraturan Menteri Pekerjaan Uum No. 05/PRT/M/2008. Pedoman

Penyediaan dan Pemanfaatan Ruang terbuka Hijau di Kawasan Perkotaan.

Rachmawati, Reny. (2013). Tesis : Perancangan Lansekap Sempadan Sungai Mati Cisangkuy sebagai Ruang Terbuka HIjau Publik. ITB.

Rohmat, Dede. (2009). Solusi Aspiratif Penanganan Masalah Sungai Mati (Kasus: Desa Andir Kecamatan Baleendah Kabupaten Bandung). Dimuat pada Jurnal GEA. 
Sjafruddin, Ade. (2012). Bahan Kuliah Studi Kelayakan dan Pendanaan Infrastruktur. Teknik Sipil - ITB.

Soekartawi. (1995). Dasar Penyusunan Evaluasi Proyek. Jakarta : Pustaka Sinar Harapan.

Sosrodarsono, Suyono, Masateru Tominaga. (1994). Perbaikan dan Pengaturan Sungai. Jakarta: PT. Pradnya Paramita.

Suyatno, Adi.,Trie M. Sunaryo., Roestam Syarief. (2003). Ekonomi Teknik Proyek Sumber Daya Air. Jakarta: PT. Medisa.

Tang, Siu Lam. (1991). Economic Feasibility of Project. McGraw-Hill Book Singapore. 